\title{
THE EXPERIENCE OF SCHOOL BULLYING. PERCEPTIONS AND ATTITUDES OF STUDENTS ON THE PHENOMENON
}

\author{
$\begin{array}{lll}\text { M.C. BULARCA } & & \text { A. POPESCU } \\ & \text { A. SIMA } & \\ & \end{array}$ \\ D.S. BĂLĂUṬĂ ${ }^{4} \quad$ O.L. FILIP ${ }^{5}$
}

\begin{abstract}
The paper aims to study both perceptions and attitudes, as well as bullying experiences in middle school and high school students, in urban areas (Drobeta Turnu Severin) and rural areas (Burila Mare, Vânători), Mehedinți County, given the differences in age, gender and background. A questionnaire was applied to 94 students, and the results show that $50 \%$ of respondents often or very often observe aggressive behaviour in their schools. The phenomenon is more frequent in the urban area, out of a total of $59.57 \%$ of respondents, $30.85 \%$ confessing that they observe such behaviour in school; among students aged between 15 and 17, females were most affected with a percentage that far exceeds the male gender.
\end{abstract}

Key words: bullying, victim, school violence

\section{Introduction}

\subsection{Conceptual delimitations}

Bullying is a complex and widespread problem that affects both children of all ages and adults. Representations of bullying in countless books and movies portray the victims of the phenomenon as resilient and victorious, while the aggressor ends up facing justice. In reality, however, such an optimistic view has been tempered even by suicides, accompanied by a literature that shows how serious and widespread the consequences of harassment are.

Current thinking now reflects an understanding of bullying as a social and cultural phenomenon associated with serious long-term physical and psychological

\footnotetext{
${ }^{1}$ Transilvania University of Brașov, cristina.bularca@unitbv.ro, corresponding author

${ }^{2}$ West University of Timișoara, ana.popescu13@e-uvt.ro

${ }^{3}$ West University of Timisoara, andreea.sima00@e-uvt.ro

${ }^{4}$ West University of Timisoara, danut.balauta@e-uvt.ro

5 „Babeș - Bolyai” University - UBB University Resita Center, oana.filip@ubbcluj.ro
} 
consequences for aggressors, victims and those who oscillate between the two roles. Existing research suggests that harassment may be common and not harmless.

The media has presented many cases of chronic victims who brutally take revenge on their aggressors. Chronic bullies tend to resume using power relations in their adult lives (Olweus, 1978). The quality of school life of victims is affected to the point where a significant number of victims report social and academic trauma resulting from harassment by colleagues (Hoover et al., 1992). This can have serious implications for the development of competent social relationships. Finally, socially isolated people, including many victims of harassment, are absent and drop out of school at a higher rate than their peers (Roff, Sells, \& Golden, 1972).

The term bullying refers to a negative action performed intentionally, repeatedly, in which there is an imbalance of power. Bullying includes both physical and psychological aggression (Olweus, 1978), and victims have stated that bullying consists of behaviors such as teasing, ridicule, vandalism of personal belongings, and physical violence. (Hoover et al., 1992). Usually, the aggressor chooses a weaker victim, who will be repeatedly assaulted (Meszaros, Goian, Vlaicu \& Bălăuță, 2020). In this regard, bulying can be associated with the concept of manipulation, which implies the alteration of attitudes, beliefs and behaviors of a person or social group, in conformity with the interests of the initiator of the manipulation process, thus leaving the people exposed to the manipulation belive they have freedom of thinking and freedom to take action (Coman, 2007, p.33).

The phenomenon is represented by three characteristics: (1) the negative action is performed intentionally, the aggressor having the will / desire to hurt someone, (2) it is repeated, in the sense that a person is assaulted more than once, (3) in the exercise of the action there is an imbalance of power, the aggressors choosing weaker victims, who cannot defend themselves. It is initially perceived as a game, but it can very easily become an abuse with extremely serious repercussions.

\subsection{Forms of bullying}

The increase of interest in this field has led to the distinction of several forms of the phenomenon, which may include different types of behaviors grouped under the term. Limber (2002) compiles a model for classifying the common forms of bullying encountered in schools. It divides bullying into three categories, namely: verbal forms of the behavior, such as insults, gossip, provocation / instigation, teasing, etc.; physical forms, such as hitting, pushing, destroying, or stealing personal items, and persuading someone else to attack and, last but not least, the third category, non-verbal / nonphysical forms of bullying - threats, obscene gestures and the exclusion of others from a group, threatening e-mails, etc.

Dodge (1991) introduced the notion of two types of aggression: proactive aggression and reactive aggression. Reactive aggression involves angry and defensive reactions to frustration, while proactive aggression is characterized by goal-oriented, dominant, and coercive behavior. 
A person with proactive aggression has cold blood and will use aggression to achieve their goal. On the other hand, reactive aggressors often misinterpret the gestures of those around them (Camodeca et al., 2003). Thus, although bullying and its forms of aggresions can have multiple causes, bullying actions can also happen due to the negative image people have about each other. In this regard, an image can be considered a "mental construct, a representation that results from the way we perceive the characteristics of an object, event or person". Thus, in the context of this definition an image is subjective, because it is the result of a mental construct, and an image influences the way people perceice things because it creates a representation regarding the way things are (Coman, 2018).

Furthermore, since the messages sent through various communication channels have the power to influence different types of public (Coman et al., 2018, p.41), in the context of middle school and high-school students, their agresive attitudes could also be influenced by the information they gather from the mass - media channels they use.

\subsection{Gender differences in bullying}

Gender differences were observed in school aggression. An extensive body of literature suggests that boys are more likely than girls to be both aggressors and victims. (Boulton and Smith, 1994) Although "masculinity" itself is probably not a causal factor as some have suggested (Egger, 1995), the social and situational forces that combine with masculinity may be a factor. Thus, school bullying seems to be more common among boys and students in lower secondary education. For example, Rigby and Slee (1993) identified $10 \%$ of 201 boys between the ages of 7 and 13, compared with $6 \%$ of 211 girls who were victims of school bullying. Girls, however, may engage in more hidden forms of indirect aggressive behaviour, such as spreading rumors, social rejection, and exclusion.

\subsection{Roles in bullying}

In addition to the traditional roles of aggressor, victim and non-involved persons, a series of studies assess the situation of victims who in turn provoke or are aggressive, children who have characteristics of both the aggressor and the victim. Not surprisingly, some studies suggest that these children are more at risk than "pure bullies" or "pure victims" (Duncan, 1999; Wolke et al., 2000).

The work of Salmivalli and colleagues (1996) opened the subject of the dynamics of aggression, suggesting that young aggressors could be considered either leaders (those who organize a group of aggressors and initiate aggression) or followers (those who join the aggression once it started), as well as those who instigate and intensify aggression (who do not actively join, they just watch and laugh or encourage aggression). Salmivalli also distinguished outsiders (who are completely uninvolved) and defenders (who help the victim or tell the bullies to stop). 


\subsection{Statistics from Romania}

A study conducted by Save the Children in 2016, highlighted the following aspects:

- $31 \%$ of students stated that they were excluded from group activities, and another $23 \%$ were threatened with exclusion from the group.

- cases of humiliation of students in front of others are presented in a percentage of $23 \%$, while $37 \%$ of students endured gossip or negative words.

- Regarding the situations of physical aggression, the data shows that $13 \%$ of the students faced the destruction of personal belongings by other students, $30 \%$ of them said that they were subjected to repeated beatings in school by other colleagues.

- $68 \%$ of cyberbullying cases are reported, most of which take place on social networks.

In the same study, the research carried out by the World Health Organization (WHO) is mentioned, in which the results illustrated the situation of children by different age groups, so that the first category is that of 11 -year-old children, represented by $17 \%$, who subjected other children to aggression several times in a month, and the category of children aged 13-15 years, with a percentage of 23\%, the difference being $6 \%$ between the two categories. The data processed for this situation, provided by the Ministry of National Education for the 2014-2015 school year, indicated over 18,500 cases of violence in the country.

\section{Method}

\subsection{Research Aim}

The purpose of the research refers to the assessment of the degree of exercise of the bullying phenomenon in schools, and the exploration of students' perceptions and attitudes towards this phenomenon.

\subsection{Objectives}

This research aims to ascertain the frequency of bullying both in rural schools and in urban schools, by comparing the experience of the phenomenon according to by different categories, such as: age, sex, background, and the attitudes of students towards the experience of bullying.

\subsection{Hypotheses}

1. The background influences the degree of exercising the bullying phenomenon.

2. The experience of bullying affects women more intensely.

3. The incidence of bullying is influenced by gender.

4. Age influences the degree of bullying between students. 


\subsection{Data Collection and Respondents}

To conduct the research, we used the quantitative research method. This research was carried out in Mehedinți county, both in urban and rural areas, with the help of 100 students enrolled in grades V-XII, from the National Pedagogical College "Stefan Odobleja", "Theodor Costescu" Secondary School, Burila Mare Secondary School and Vânatori Secondary School.

The questionnaire, made with the help of the Google Forms platform, was used as a tool for the research. It consists of 25 questions. The first part of the questionnaire presents identification and accommodation questions, such as age, gender, background, etc., and gradually questions are used to analyze students' experiences, perceptions, and attitudes regarding bullying. The data was collected exclusively online, the questionnaire was distributed on social networks, such as Facebook, WhatsApp, or e-mail.

After collecting the data, we created a database using Microsoft Excel. The students presented their agreement regarding the completion of the questionnaire, they were informed from the beginning on all aspects related to the research, questionnaire anonymity, etc. Among the possible limitations of the research, we can list students' insincere completion of the questionnaire, or its partial completion, and a small number of respondents.

\section{Results}

Aggressive behaviour

Table 1

\begin{tabular}{|l|c|c|}
\hline \multirow{2}{*}{} & \multicolumn{2}{|c|}{ How often have you noticed aggressive behavior in your school? } \\
\cline { 2 - 3 } & Frequency & Percentage \\
\hline Never & 5 & $5,32 \%$ \\
\hline Often & 38 & $40,43 \%$ \\
\hline Very often & 9 & $9,57 \%$ \\
\hline Very rarely & 10 & $10,64 \%$ \\
\hline Rarely & 32 & $34,04 \%$ \\
\hline Total & $\mathbf{9 4}$ & $\mathbf{1 0 0 , 0 0 \%}$ \\
\hline
\end{tabular}

Opinions regarding the observation of the frequency of bullying in schools are divided equally among students. While 47 respondents $(50 \%)$ claim that in their school violence is encountered often and very often, the other half of respondents, another 47 (50\%) mention that in their school violence is encountered rarely, very rarely or never.

Victims of bullying

Table 2

\begin{tabular}{|l|c|c|}
\hline \multirow{2}{*}{} & \multicolumn{2}{|c|}{ Have you ever been the target of bullying / violence? } \\
\cline { 2 - 3 } & Frequency & Percentage \\
\hline Yes & 41 & $43,62 \%$ \\
\hline No & 53 & $56,38 \%$ \\
\hline Total & $\mathbf{9 4}$ & $\mathbf{1 0 0 , 0 0 \%}$ \\
\hline
\end{tabular}


The number of bullying cases among students is lower than the number of those who were not the target of the phenomenon, but not by much, the difference in percentages between these two categories being $12.76 \%$, respectively 12 students.

The background and aggressive behaviour

Table 3

\begin{tabular}{|l|c|c|c|}
\hline \multicolumn{1}{|c|}{$\begin{array}{c}\text { How often have you noticed aggressive behavior in your } \\
\text { school? }\end{array}$} & \multicolumn{3}{c|}{ Background } \\
\hline & rural & urban & Total \\
\hline Never & $5,32 \%$ & $0,00 \%$ & $5,32 \%$ \\
\hline Often & $12,77 \%$ & $27,66 \%$ & $40,43 \%$ \\
\hline Very often & $6,38 \%$ & $3,19 \%$ & $9,57 \%$ \\
\hline Very rarely rar & $0,00 \%$ & $10,64 \%$ & $10,64 \%$ \\
\hline Rarely & $15,96 \%$ & $18,09 \%$ & $34,04 \%$ \\
\hline Total & $\mathbf{4 0 , 4 3 \%}$ & $\mathbf{5 9 , 5 7 \%}$ & $\mathbf{1 0 0 , 0 0 \%}$ \\
\hline
\end{tabular}

Aggressive behavior is observed more often in the urban area than in the rural area. The percentage of respondents who observed such behavior often and very often was $30.85 \%$ in urban areas, while in rural areas the percentage is $19.15 \%$, the difference being almost 12 percent.

The background influences the frequency of aggressive behavior

Table 4

\begin{tabular}{|l|c|c|c|}
\hline $\begin{array}{l}\text { How often have the following happened to you: Have you } \\
\text { seen a child humiliate or shame another child }\end{array}$ & \multicolumn{3}{|c|}{ Age } \\
\hline & rural & urban & Total \\
\hline Never & $6,38 \%$ & $11,70 \%$ & $18,09 \%$ \\
\hline Often & $10,64 \%$ & $23,40 \%$ & $34,04 \%$ \\
\hline Very often & $6,38 \%$ & $3,19 \%$ & $9,57 \%$ \\
\hline Very rarely & $9,57 \%$ & $6,38 \%$ & $15,96 \%$ \\
\hline Rarely & $7,45 \%$ & $14,89 \%$ & $22,34 \%$ \\
\hline Total & $\mathbf{4 0 , 4 3 \%}$ & $\mathbf{5 9 , 5 7 \%}$ & $\mathbf{1 0 0 , 0 0 \%}$ \\
\hline
\end{tabular}

Regarding the way in which bullying is manifested by humiliation, it is more common in the urban area, there is a difference of 10 percent between the two categories. From the analysis of the two tables, we can conclude that the phenomenon of bullying is more common in urban areas than in rural areas, the difference in percentages between the two averages being in both cases 10 or over 10 percent. 
Gender influences the bullying phenomenon

Table 5

\begin{tabular}{|l|r|r|r|}
\hline $\begin{array}{l}\text { How often have the following situations happened to } \\
\text { you: Threatening to hit or the hitting of another child }\end{array}$ & \multicolumn{3}{|c|}{ Gender } \\
\hline & female & \multicolumn{1}{|c|}{ male } & \multicolumn{1}{c|}{ Total } \\
\hline Never & $47,87 \%$ & $26,60 \%$ & $74,47 \%$ \\
\hline Often & $0,00 \%$ & $1,06 \%$ & $1,06 \%$ \\
\hline Very often & $1,06 \%$ & $0,00 \%$ & $1,06 \%$ \\
\hline Very rarely & $7,45 \%$ & $9,57 \%$ & $17,02 \%$ \\
\hline Rarely & $1,06 \%$ & $5,32 \%$ & $6,38 \%$ \\
\hline Total & $\mathbf{5 7 , 4 5 \%}$ & $\mathbf{4 2 , 5 5 \%}$ & $\mathbf{1 0 0 , 0 0 \%}$ \\
\hline
\end{tabular}

We notice a slight increase in the manifestation of threats among males, in the sense that they offered more answers in the category "rare" or "very rarely" and fewer responses in the category called "never".

Gender influences the exercise of the bullying phenomenon

Table 6

\begin{tabular}{|l|c|c|c|}
\hline $\begin{array}{l}\text { How often have the following happened to you: To } \\
\text { humiliate or shame another child }\end{array}$ & \multicolumn{3}{|c|}{ Gender } \\
\hline & female & male & Total \\
\hline Never & $50,00 \%$ & $34,04 \%$ & $84,04 \%$ \\
\hline Very rarely & $4,26 \%$ & $6,38 \%$ & $10,64 \%$ \\
\hline Rarely & $3,19 \%$ & $2,13 \%$ & $5,32 \%$ \\
\hline Total & $\mathbf{5 7 , 4 5 \%}$ & $\mathbf{4 2 , 5 5 \%}$ & $\mathbf{1 0 0 , 0 0 \%}$ \\
\hline
\end{tabular}

As it results from the analysis of the two crosstabs, we can say that there is a connection between the launched hypothesis and the analysis of the obtained results. The frequency with which bullying is manifested through humiliation or embarrassment of other students is slightly higher among boys than among girls.

\begin{tabular}{|l|c|c|c|c|}
\hline $\begin{array}{l}\text { How often have the following happened to you: } \\
\text { To humiliate or shame another child }\end{array}$ & \multicolumn{4}{|c|}{ Age } \\
\hline & $\mathbf{1 2 - 1 4}$ & $\mathbf{1 5 - 1 7}$ & $\mathbf{1 8 - 1 9}$ & Total \\
\hline Never & $32,98 \%$ & $50 \%$ & $1,06 \%$ & $84,04 \%$ \\
\hline Very rarely & $3,19 \%$ & $7,45 \%$ & $0,00 \%$ & $10,64 \%$ \\
\hline Rarely & $3,19 \%$ & $1,06 \%$ & $1,06 \%$ & $5,32 \%$ \\
\hline Total & $\mathbf{3 9 , 3 6 \%}$ & $\mathbf{5 8 , 5 1 \%}$ & $\mathbf{2 , 1 2 \%}$ & $\mathbf{1 0 0 , 0 0 \%}$ \\
\hline
\end{tabular}


Respondents aged between 15 and 17 are more likely to humiliate or embarrass their colleagues, but there is not much difference between this category and that of respondents aged between 12 and 14 .

Age influences the degree of the bullying phenomenon

Table 8

\begin{tabular}{|l|c|c|c|c|}
\hline $\begin{array}{l}\text { How often have the following situations } \\
\text { happened to you: Spreading rumors about } \\
\text { other children }\end{array}$ & \multicolumn{4}{|c|}{ Age } \\
\hline & $\mathbf{1 2 - 1 4}$ & $\mathbf{1 5 - 1 7}$ & $\mathbf{1 8 - 1 9}$ & Total \\
\hline Very often & $25,53 \%$ & $40,42 \%$ & $1,06 \%$ & $67,02 \%$ \\
\hline Often & $2,13 \%$ & $1,06 \%$ & $1,06 \%$ & $4,26 \%$ \\
\hline Very rarely & $6,38 \%$ & $11,07 \%$ & $0,00 \%$ & $18,09 \%$ \\
\hline Rarely & $5,32 \%$ & $5,32 \%$ & $0,00 \%$ & $10,64 \%$ \\
\hline Total & $\mathbf{3 9 , 3 6 \%}$ & $\mathbf{5 8 , 5 1 \%}$ & $\mathbf{2 , 1 2 \%}$ & $\mathbf{1 0 0 , 0 0 \%}$ \\
\hline
\end{tabular}

By analyzing the two tables, we can conclude that age can be a factor that influences the degree of exercise of the bullying phenomenon, so the hypothesis created is consistent with the responses.

\section{Conclusions}

Through the research, it is known that $50 \%$ of the students who took part, very often and often observe aggressive behaviors in school (40.43\% - often; 9.57\% - very often), and $43,62 \%$ were victims of this phenomenon. At the same time, making a comparison between the areas of origin, we found that the bullying phenomenon predominates in the urban area, with a percentage of $30.85 \%$, being almost 12 percent higher than rural areas (19.15\% - rural area).

Gender and age differences have been reported in some aspects of school violence. The analysis of the research shows that the most affected by the bullying phenomenon are girls, out of a total of $57.45 \%$ of female respondents, $28.72 \%$ confessing that they were the target of this phenomenon, while of the $42.55 \%$ of male respondents, only $14.89 \%$ confessed to being victims.

This was also found in the research "Aggression in students" conducted by BeldeanGalea loana-Elena, at the University "BABESS-BOLYAI" in Cluj-Napoca, Faculty of Psychology and Educational Sciences: "girls need healthcare more often than boys after a fight with other students, are more frequently insulted, mocked, pushed or hit, harassed" (Beldean-Galea, 2012).

Regarding the comparison of the phenomenon according to age categories, there is a slight increase in respondents aged between 15 and 17, but there is no significant difference. Therefore, the phenomenon of bullying is also present in the areas studied in the research, and it is found in both rural and urban areas, at all age groups, with slight differences in percentage between them and it affects especially women, but the male gender is not protected from this phenomenon either. 
Bullying is among various problems in the school environment, so parents, teachers but also the community must support children and solve these issues (Bălăuță, Borcovici \& Vlaicu, 2017). For teachers experiencing burnout, monitoring students may be difficult (Goian, 2014) and communication with children that are victims of bullying should ensure that their status is not worsened (Goian, 2010), but it is still a paramount duty of education staff to support students.

\section{References}

Bălăuță D.S, Borcovici, R., Vlaicu, L. (2017). School social work - between reality and desideratum. Agora Psycho-Pragmatica, 11 (2), 76-82.

Beldean-Galea, I.-E. (2012). Agresivitatea la elevi [Agression in students]. [Doctoral thesis], Cluj Napoca: Universitatea Babes- Bolyai.

Boulton, M. J., \& Smith, P. K. (1994). Bully-victim problems in middleschool children: Stability, self-perceived competence, peer perceptions and peer acceptance. British Journal of Developmental Psychology, 12, 315-329. doi:10.1111/j.2044835X.1994.tb00637.

Camodeca, M., Goossens, F. A., Schuengel, C., \& Terwogt, M. M. (2003). Links between social information processing in middle childhood and involvement in bullying. Aggressive Behavior, 29(2), 116-127. https://doi.org/10.1002/ab.10043

Coman, C. (2007). Tehnici de negociere. [Negotiation techniques] Bucuresti: CH Beck.

Coman, C. (2018). Analiza imaginii și influența Mass media. Image analysis and Mass media influence] Timișoara: West Publishing.

Coman, C., Rezeanu, C. I., \& Mihalte, S. I. (2018). Highlighting The Image Of The Local Government Institutions In Mass Media Based On The Results Of The Content Analysis. Curentul Juridic, The Juridical Current, Le Courant Juridique, 72, 39-56.

Dodge, K.A. (1991). The structure and function of reactive and proactive aggression. În: Pepler DJ, Rubin, KH, editors. The development and treatment of childhood aggression. Hillsdale, NJ: Lawrence Erlbaum. 201-218.

Duncan, R. D. (1999). Peer and sibling aggression: An investigation of intra- and extrafamilial bullying. Journal of Interpersonal Violence, 14, 871-886.

Goian, C. (2010). Zece categorii de inconsecvențe semantice prezente în limbajul asistenței sociale din spațiul românesc. [Ten Categories of Inconsequentialities in the Romanian Social Work Language]. Revista de Asistenţă Socială, Issue 1, pp. 79-90.

Goian, C. (2014). Transnational Wellbeing Analysis of the Needs of Professionals and Learners Engaged in Adult Education. Procedia - Social and Behavioral Sciences, Vol. 142, pp. 380-388, https://doi.org/10.1016/j.sbspro.2014.07.695 .

Hoover, J. H., Oliver, R., \& Hazler, R. J. (1992). Bullying: Perceptions of Adolescent Victims in the Midwestern USA. School Psychology International, 13(1), 5-16. https://doi.org/10.1177/0143034392131001

Limber, S.P. (2002). Addressing youth bullying behaviors. In Proceedings of the Educational forum on Adolescent Health on YouthBullying, Chicago: American Medical Assosiation. 
Meszaros, A., Goian C., Vlaicu, L., Bălăuță, D.S. (2020). A comparative analysis between the perceptions and attitudes of students in two high schools with different status regarding the phenomenon of bullying in schools. Journal Plus Education, Vol. XXV, No. $1 / 2020$, pp. 308-325.

Olweus, D. (1993). Bullying at school: What we know and what we can do. Oxford, U.K.: Blackwell.

Rigby, K., Slee, P. (1991). Bollying among Australian schoolchildren: Reported behaviour and attitudes toward victims. The Journal of Social Psychology, 13, 615-627.

Roff, M., Sells, S. B., \& Golden, M. M. (1972). Social adjustment and personality development in children. Mineapolis, London, U. Minnesota Press.

Salmivalli, C., Lagerspetz, K., K., O" sterman, K., \& Kaukiainen, A. (1996). Bullying as a group process: Participant roles and their relations to social status within the group. Aggressive Behavior, 22, 1-15.

Wolke, D., Woods, S., Bloomfield, L., \& Karstadt, L. (2000). The association between direct and relational bullying and behaviour problems among primary school children. Journal of Child Psychology and Psychiatry, 8, 989-1002. 